\title{
THE 1551 HERBERSTEIN-WERNHER DESCRIPTION OF LAKE CERKNICA
}

\author{
HERBERSTEIN - WERNHERJEV OPIS CERKNIŠKEGA JEZERA \\ IZ LETA 1551
}

\author{
Primož SIMONITI ${ }^{1}$
}

\begin{abstract}
UDC 094.1:551.44(497.4 Cerknica):929 Wernher G. Primož Simoniti: The 1551 Herberstein-Wernher Description of Lake Cerknica

In 1551, Georg Wernher sent into print in Vienna his work De admirandis Hungariae aquis hypomnemation, which included a description of Lake Cerknica. Baron Sigismund von Herberstein, on whose initiative the work had been written, had conveyed to Wernher an oral description of the lake; the question whether he had written it down as well, as might be inferred from the references in J. W. Valvasor (1689), can no longer be answered. Herberstein may be considered to have not only alerted Wernher to the lake, but also to have (co)authored the report on the lake. There is nothing in the text to suggest that Wernher had ever visited or investigated the lake himself. In addition, Herberstein commissioned a woodcut showing a map of the lake, presumably based on a drawing by Augustin Hirschvogel. The paper cites the relevant passages both in the Latin original and in an English translation.

Keywords: history of karstology, Lake Cerknica, Georg Wernher, Sigismund von Herberstein, Augustin Hirschvogel, Johann Weichard Valvasor.
\end{abstract}

In September 1551, a Viennese printer, Aegidius Aquila, printed a work entitled De admirandis Hungariae aquis hypomnemation (Wernher 1551). The author's name is given as Georgius Wernherus, and the very title page reveals that he had dedicated his treatise to the famous Baron Sigismund von Herberstein (1486-1566), with whose magnificent woodcut coat-of-arms the title page is adorned. The long title runs as follows:
Izvleček UDK 094.1:551.44(497.4 Cerknica):929 Wernher G. Primož Simoniti: Herberstein-Wernherjev opis Cerkniškega jezera

Georg Wernher je dal 1551 na Dunaju natisniti delo De admirandis Hungariae aquis hypomnemation, v katerega je vpletel tudi opis Cerkniškega jezera. Baron Sigismund Herberstein, ki je dal pobudo za nastanek dela, je Wernherju posredoval ustni opis jezera; ali ga je opisal tudi v pisni obliki, kakor je mogoče sklepati po navedbah pri J. W. Valvasorju (1689), je danes neugotovljivo. Herbersteina je mogoče šteti ne le za osebo, ki je Wernherja opozorila na jezero, ampak za (so)avtorja poročila o jezeru. V tekstu ni nobenega indica za domnevo, da je Wernher kdaj obiskal jezero in ga raziskoval. Herberstein je poskrbel tudi za lesorez z zemljevidom jezera, za katerega je najbrž izdelal risarsko predlogo Augustin Hirschvogel. Članek prinaša zadevne partije v latinskem izvirniku in slovenskem prevodu.

Ključne besede: zgodovina krasoslovja, Cerkniško jezero, Georg Wernher, Sigismund Herberstein, Augustin Hirschvogel, Johann Weichard Valvasor.
Dunajski tiskar Aegidius Aquila je septembra 1551 natisnil delo De admirandis Hungariae aquis hypomnemation (Wernher 1551). Kot avtor je naveden Georgius Wernherus, že z naslovne strani pa je razvidno, da je svoje delce posvetil slovitemu baronu Sigismundu Herbersteinu, čigar razkošni lesorezni grb tudi krasi naslovnico. Dolgi naslov se glasi:

\footnotetext{
${ }^{1}$ Professor Emeritus of the Faculty of Arts, University of Ljubljana, Javorjev drevored 9, 1000 Ljubljana, Slovenia, e-mail: primoz.simoniti@guest.arnes.si.
}

Received/Prejeto: 23.2.2010 


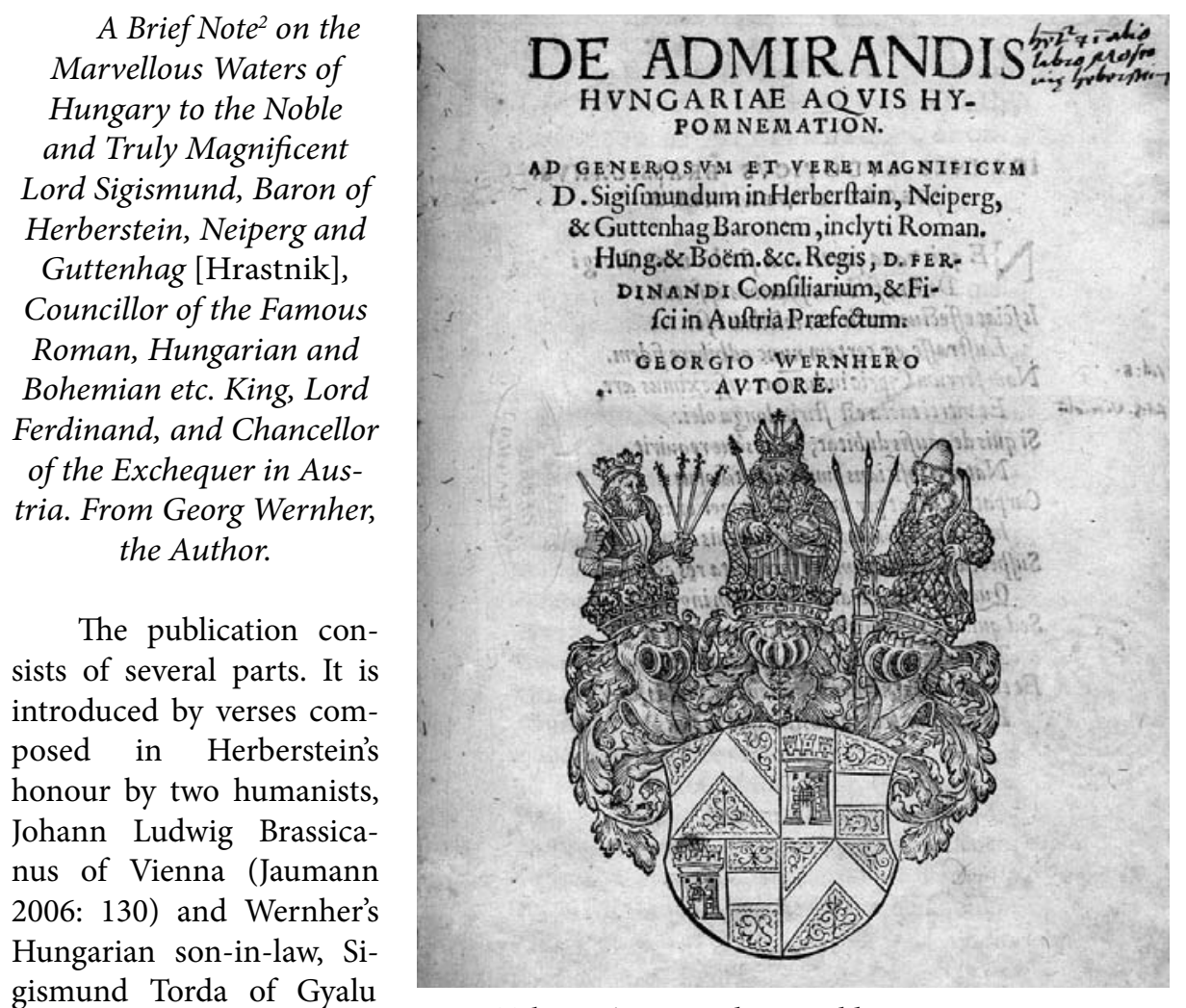

gismund Torda of Gyalu (Romanian Gilau, German Julmarkt; on Torda, see Denis 1782: 514). There follows an undated letter (the Latin original is given in the Appendix) addressed by Herberstein to Wernher, exhorting the latter to take up a systematic research into and description of the unusual phenomena observed in the waters of Hungary, since the Baron is keenly interested in these matters:

Sigismund, Free Baron of Herberstein, Neiperg and Guttenhag [Hrastnik] etc., to Georg Wernher, Royal Councillor and Mayor of Saros, ${ }^{3}$ greetings!

\footnotetext{
${ }^{1}$ The upper right corner bears a handwritten note: habetur et in alio libro Moscouie Herbersteinij - "it is in the second book of Herberstein's Moscovia as well".

${ }^{2}$ Hypomnemation, Latin commentariolus, denotes a 'short memorandum'. The author himself renders the term in German as Khurzer Bericht (Werner 1558).

3 Šrišský hrad, in the Middle Ages the Mayor's seat, which gave its name to the former comitatus (county) Sáros vármegye, i.e., Šariš in northeastern Slovakia, Latin comitatus Sarossiensis, German Scharosch.
}

Kratko poročilo ${ }^{2} o$ čudovitih vodah Ogrske žlahtnemu in resnično veličastnemu gospodu Sigismundu, baronu Herbersteinu, Neipergu in Hrastniškemu, svetniku slavnega rimskega, ogrskega in češkega itn. kralja Ferdinanda in predstojniku blagajne v Avstriji, avtorja Georga Wernherja.

Celotno delo ima nekaj sestavin. Najprej so Herbersteinu na čast natisnjeni počastilni verzi dveh humanistov, dunajskega Johanna Ludwiga Brassicana (Jaumann 2006: 130) in ogrskega, Wernherjevega zeta, Sigismunda Torde iz Gyaluja (rom. Gilau, nem. Julmark; o njem Denis 1782: 514). Sledi sicer nedatirano pismo (latinski izvirnik v Prilogi), ki ga je Herberstein naslovil na Wernherja in le-tega $\mathrm{v}$ njem spodbujal, naj se sistematično loti raziskovanja in opisovanja nenavadnih pojavov, ki jih je opaziti na vodah po Ogrskem, saj da te stvari barona živo zanimajo:

Sigismund, svobodni baron Herberstein, Neiperg in Hrastniški itd., Georgu Wernherju, kraljevemu svetniku in županu pri Šarišu $u^{3}$, pozdrav!

\footnotetext{
${ }^{1}$ Desno zgoraj pripis: habetur et in alio libro Moscouie Herbersteinij - » je tudi v drugi knjigi Herbersteinove Moskovije«.

${ }^{2}$ Hypomnemation, lat. commentariolus, bi pravzaprav pomenilo krajše zapiske v oporo spominu. Sam avtor je v nemščini uporabil izraz Khurzer Bericht (Wernher 1558).

3 Šarišský hrad, v sr. veku županov sedež, po katerem je dobil ime nekdanji komitat (županija) Sáros vármegye, tj. Šariš na sverovzhodnem Slovaškem, lat. comitatus Sarossiensis, nem. Scharosch.
} 
Although I had heard long ago, and from many people, much about the marvellous waters of Zepusium, ${ }^{4} I$ nevertheless wished to be informed of these matters, which seemed incredible to most people, principally by you, and to hear your judgment. And since you did not hesitate to write to me what you had learnt about them, you effected easily not only that I myself have been sure ever since what to think of them, but that many other excellent gentlemen, too, have ceased doubting, reassured by your testimony, which carries the highest authority with all. But since the other parts of Hungary are likewise said to abound in waters no less marvellous, you will perform a great service to me, and to many others who are desirous of such knowledge and devoted to you, if you undertake a description of these as well. I know, of course, and I saw with my own eyes, serving as an envoy from the divine Emperor Maximilian to the illustrious late King Ludovicus of Hungary at the royal seat in Buda, that there are to be found thermal springs too hot to plunge your arm underwater, which naturally seems marvellous to anyone who has not seen the like before. But that there should even be live fish in these waters is considered incredible by not a few. Of a similar nature seems to be the rumour of other thermal springs, those on the bank of the Vagus [Vacha] River, not far from the town of Galgocz, ${ }^{5}$ popularly called Freistat by the Germans and the Slavs; it is said of these that they regularly change their position, always by the same distance, as the river rises or sinks. I have but recently read in the third book of Arrian ${ }^{6}$ the description of a spring which flows into the open with lukewarm water and grows cold by noon, warm by the evening, and lukewarm again by daybreak, thus alternating between warmth and coolness every day and night. According to Saxo Grammaticus, ${ }^{7}$ on the other hand, there is a spring in Iceland which destroys, by the fault of its steaming water, the original nature of any thing. For whatever is breathed upon by its humid vapour is suddenly transmuted to stony hardness, with nothing but its form remaining. Now the readers of these and similar accounts will marvel less when they notice that the supreme

\footnotetext{
${ }^{4}$ Formerly comitatus Szepes vármegye (bordering on the comitatus Sarossiensis), i.e., Spiš, Latin comitatus Cepusiensis (Sepusium, Scepusium, Zepusium), German Zips, Polish Spisz.

${ }^{5}$ The Slovak Hlohovec, popularly called Fraštak; Galgócz in Hungarian and Freistadt in German; a town in western Slovakia.

${ }^{6}$ Flavios Arrianos (Greek historiographer, $2^{\text {nd }}$ century AD), Alexandri Anabasis 3.4 (description of a spring near Ammon's Libyan temple).

${ }^{7}$ Saxo Grammaticus, Danish historiographer (cca. 1150-cca. 1220), Gesta Danorum [Danorum Regum heroumque Historia stilo eleganti a Saxone Grammatico ... conscripta, primum ed. Christian Petri, Apud Parrhisios, Jod. Badius 1514]
}

Čeprav sem že dolgo tega, in sicer od marsikoga, veliko slišal o čudovitih vodah v Spišu ${ }^{4}$, sem vendar želel biti o teh stvareh, ki so se zdele večini neverjetne, obveščen predvsem od tebe in slišati tvojo sodbo. Ker pa se nisi obotavljal pisati mi, kar si bil o tem izvedel, si zlahka dosegel, da odtlej ne le zagotovo vem, kaj moram o tem misliti, ampak da bo tvoje pričevanje, ki ima pri vseh kar največjo veljavo, tudi mnogim drugim odličnim možem zagotovilo, da se ne bodo več vdajali dvomom. Toda ker pravijo, da je tudi $v$ drugih delih Ogrske mnogo nič manj čudovitih vodá, boš naredil veliko uslugo meni in mnogim drugim ljudem, ki so željni vednosti o njih in tebi zelo privrženi, če se boš lotil opisovanja teh vodá. Vem sicer in sam sem videl, ko sem bil pri rajnkem ogrskem kralju Ludoviku odposlanec božanskega cesarja Maksimilijana, da so blizu kraljeve prestolnice Budima tako vroče toplice, da ne moreš prenesti toplote, če vtakneš roko $v$ vodo, kar se seveda zdi komu, ki tega še ni videl, prav čudno. Toda da so v tej vodi tudi žive ribe, to ima nemalo ljudi za nekaj neverjetnega. Zdi se, da so nekaj podobnega tudi govorice o drugih toplih vrelcih, ki so baje na bregu reke Vaha, nedaleč od mesta Hlohovca ${ }^{5}$, ki mu Nemci in Slovani po ljudsko rečejo Fraštak: o njih pravijo, da se prestavljajo s svojega mesta drugam $v$ zmeraj enaki razdalji, kakor že reka narašča ali upada. Pred nedavnim sem pri Arijanu $v$ tretji knjigi ${ }^{6}$ bral opis izvira, ki priteče na svetlo z mlačno vodo, opoldne je mrzel, zvečer pa se močno segreje in ob svitanju je spet mlačen, in tako vsak dan in vsako noč menjava toploto in hlad. Sakson Gramatik pa priča, da je na Islandiji izvir, $k i$ po krivdi kadeče se vode uničuje izvirno naravo katere koli stvari. Vse, česar se namreč dotaknejo njegove vlažne pare, zadobi v hitri preobrazbi naravo trde kamnine, samó oblika ostane. Ljudje, ki bodo odslej brali o teh in podobnih stvareh, se ne bodo čudili, ko bodo videli, da je najvišji Stvarnik tudi $v$ teh naših in drugih bližnjih pokrajinah postavil nemalo spomenikov svojih čudovitih del, ki pa jih domačini ne štejejo za čudež in včasih, če jih vprašaš, celó ne vedo zanje, kakor sem večkrat izkusil v Moskoviji. Ko sem namreč povprašal domačine o nekaterih stvareh te

\footnotetext{
${ }^{4}$ Šariškemu sosednji nekdanji komitat Szepes vármegye,tj. Spiš, lat. comitatus Cepusiensis (Sepusium, Scepusium, Zepusium), nem. Zips, polj. Spisz.

${ }^{5}$ Ljudsko Fraštak, madž. Galgócz, nem. Freistadt, mesto na zahodnem Slovaškem.

${ }^{6}$ Flavios Arrianos (grški zgodovinopisec iz 2. stol. po Kr.), Alexandri Anabasis 3, 4 (opis vrelca v Amonovem svetišču v Libiji).

${ }^{7}$ Saxo Grammaticus, danski historiograf (ok. 1150-ok. 1220), Gesta Danorum [Danorum Regum heroumque Historia stilo eleganti a Saxone Grammatico ... conscripta, primum ed. Christian Petri, Apud Parrhisios, Jod. Badius 1514].
} 
Creator has erected in our regions, too, as well as in adjacent ones, many monuments of His marvellous works; however, these are not considered miracles by the natives, who sometimes even prove ignorant of them if questioned, as I have often experienced in Moscovia. For when I was asking the locals about some such matters, of which I had been told by others, they had no answers and professed their wonder at where I, a foreigner, had learnt these things. There is no doubt that, had not foreign visitors observed and recorded many phenomena in various places, these would still be deprived by the locals' negligence of the light of day, of memory, and of admiration. Therefore, most honourable Wernher, I can have nothing but the highest praise for your efforts in spending such pains on unearthing and illustrating these features of your Hungary, nor can I refrain from encouraging you to continue. In this way, you will not only render a service to me but win great universal praise for yourself. Fare well.

Wernher, who took the wish of his fatherly friend almost as a command (tuo iussu), responded with a forty-page epistolary report on the waters and curiosities of the then Hungary (which included present-day Slovakia), in which he even touched upon Poland and, most importantly, added three full pages of relatively extensive description of Lake Cerknica, concluding with a brief landscape sheet displaying a woodcut panoramic map of the lake in a dry period (Fig. 2; in the modern age, the woodcut was first published by Shaw 1992: 97, Fig. 47). allusion to two spas in Switzerland. He added a double

vrste, o katerih so mi pripovedovali drugi, niso vedeli nobenega pravega odgovora, tako da so bili začudeni, od kod mi kot tujcu ta vednost. Toda ko bi zunanji obiskovalci $v$ raznih krajih ne bili opazili in popisali marsičesa, ni dvoma, da bi zaradi nebrižnosti domačinov te stvari ne prišle na svetlo in nihče se jih ne bi spominjal in jih občudoval. Zato, nadvse spoštovani Wernher, ni mogoče, da ne bi na vso moč hvalil tvoje prizadevnosti, ker svoj trud posvečaš odkrivanju in prikazovanju znamenitosti svoje Ogrske, in ne morem si kaj, da te ne bi spodbujal, da nadaljuj svoje delo. S tem boš namreč ustregel ne le meni, ampak boš tudi zase pri vseh požel veliko hvalo. Bodi mi zdrav!

Wernher je željo svojega očetovskega prijatelja razumel malodane kot ukaz (tuo iussu) in mu prav tako $\mathrm{v}$ pisemski obliki odgovoril s 40 strani dolgim poročilo o vodah in znamenitostih na takratnem Ogrskem (z današnjo Slovaško vred), se dotaknil tudi Poljske, predvsem pa dodal razmeroma obširen opis Cerkniškega jezera, ki zavzema kar cele tri strani; na koncu je še na kratko omenil dvoje toplic v Švici. Na dvojnem ležečem listu je dodal še lesorez s panoramskim zemljevidom našega jezera v sušnem obdobju (Sl. 2; lesorez je v modernem času prvi objavil Shaw 1992: 97, Fig. 47).

Preden se posvetimo vprašanju, kolikšen delež avtorstva je treba pripisati vsakemu od njiju, navedimo najprej nekaj podatkov o Georgu Wernherju (Denis 1782: 474; Bauch 1901: 75-76): po rodu je bil Šlezijec iz Paczkówa (Patschkau), študent v Wittenbergu in Krakovu, kjer je 1519 postal artistični bakalaver. Deloval je najprej kot šolnik v Košicah in Prešovu,

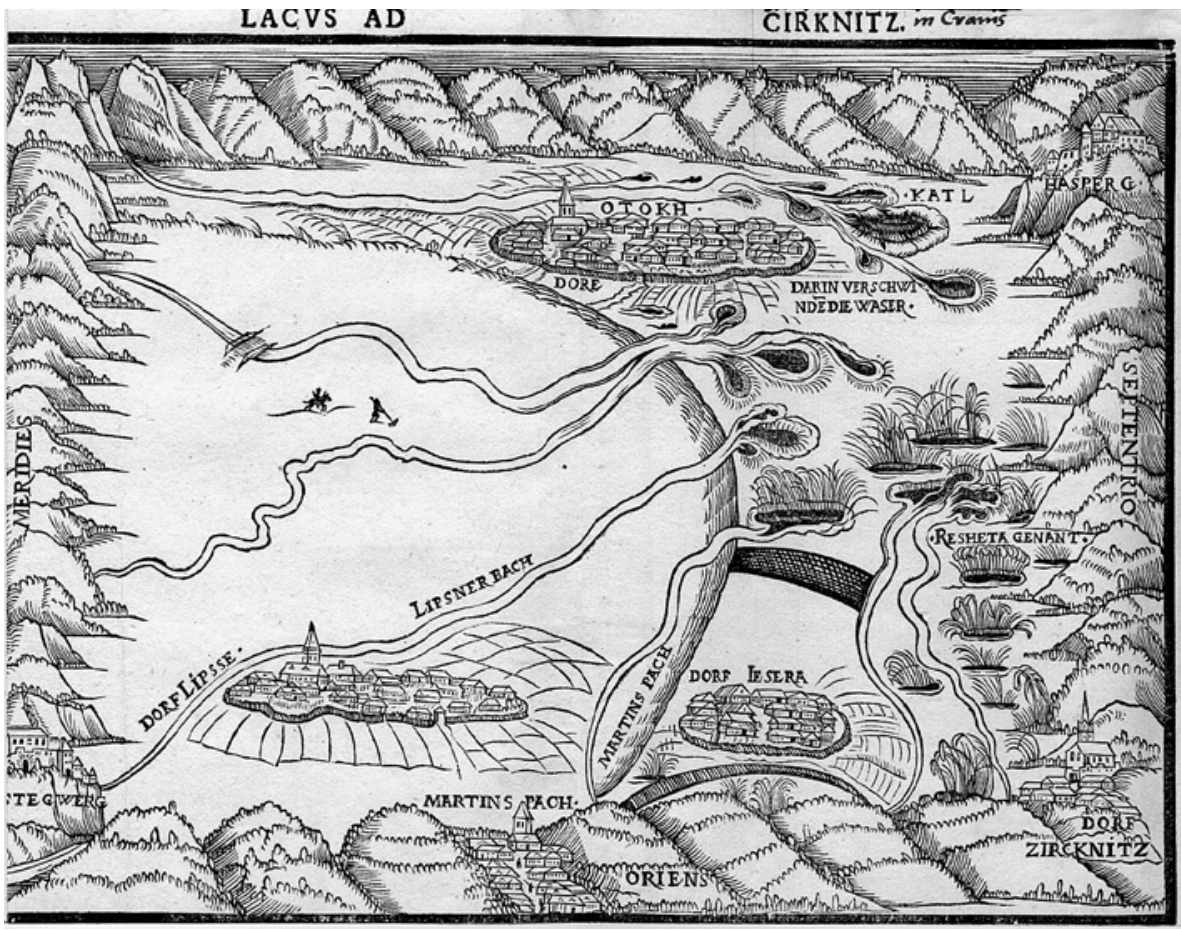
postal mestni pisar in sodnik, po bitki pri Mohácsu 1526 se je najprej udinjal Ivanu $\mathrm{Za}$ polji, nato pa ga je Herberstein priporočil kralju Ferdinandu in mož je postal kraljevi svetnik in župan komitata Šariš; po padcu Sedmograške 1551 je tam urejal habsburško upravo. Od mladih let je pisal in objavljal prigodno latinsko poezijo, menda pa je načrtoval tudi neko daljšo zgodovinsko-etnografsko razpravo o

Fig. 2: Lake Cerknica, woodcut, 1551 - Sammlung Woldan Wien, sign. G-II: OE/Hun 3.

Sl. 2: Cerkniško jezero, lesorez, 1551 - Sammlung Woldan Wien, sign. G-II: OE/Hun 3. 
Fig. 3: Lake Cerknica, copper engraving, 1595 - Sammlung Woldan Wien, sign. G-IV: EU/ Rus 54.

Sl. 3: Cerkniško jezero, bakrorez, 1595 - Sammlung Woldan Wien, sign. G-IV: EU/Rus 54.

Before addressing the respective shares of the two men in authorship, we may furnish a brief introduction of Georg Wernher (Denis 1782: 474; Bauch 1901: 7576). By birth a Silesian from Paczków (Patschkau), he studied in Wittenberg and Krakow, where he received his Bachelor of Arts degree in 1519. He began as a teacher at Košice and Prešov, conLACVSAD CIRKNITZ

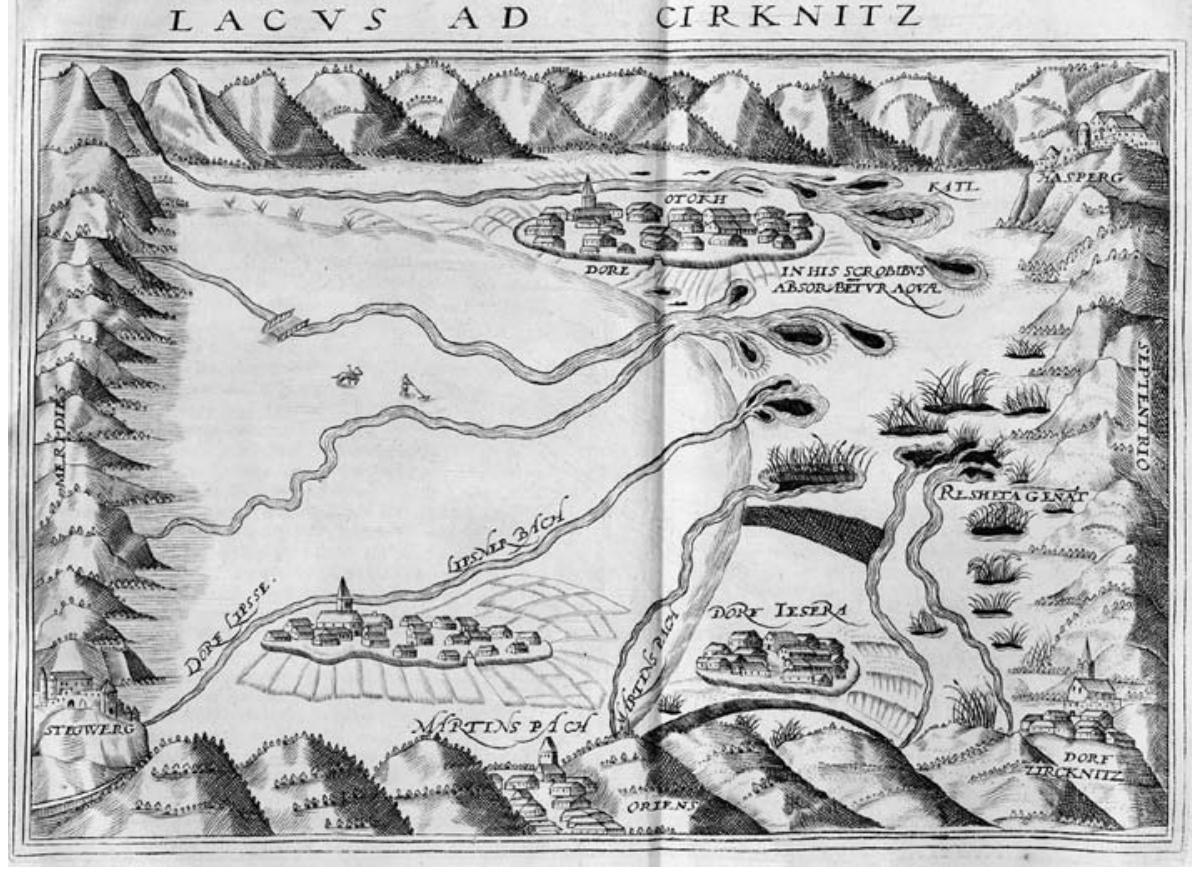
tinuing his career as a town scribe and judge; after the Battle of Mohács in 1526, he served Ivan Zapolja (John I Zápolya) at first but rose, on being recommended by Herberstein to King Ferdinand, to the positions of royal councillor and Mayor of Šariš County; after the fall of Transylvania (Siebenbürgen in German) in 1551, he was in charge of the Habsburg administration there. Since his youth he wrote and published occasional Latin poetry, and apparently planned a longer historical and ethnographic treatise on Hungary, on the origins of her peoples, names, laws, customs and institutions, ${ }^{8}$ but was forestalled by his death ca. 1557. His chief legacy is thus De admirandis Hungariae aquis hypomnemation, ${ }^{9}$ which, judging by the number of reprints, seems to have been popular reading. The first (1556) reprint, complete with all its parts except the woodcut of the lake, was commissioned in Basel by Herberstein himself (Herberstein 1556; Golia 1951: 211-214), who placed Wernher's name as conspicuously as the original publication did - that is, he did not suppress Wernher's authorship (cf. Shaw 1994: 350 and 355). The treatise, apparently highly popular with contemporary geographers and ethnographers, was soon published in German as well (Wernher 1558) and

\footnotetext{
8 "a me dicetur prolixius ea in commentatione, qua res Hungari$a e$, et populorum in ea origines, appellationes, leges, mores, instituta conor explicare." (Wernher 1551: fol.2r)

${ }^{9}$ The - usually reliable - editor of the letters of Desiderius Erasmus claims, unfortunately without adducing any evidence, that the work was written in 1528 and printed in 1551 (sic, Allen 1928: VII, 270).
}

Ogrski, izvoru njenih ljudstev, poimenovanjih, zakonih, običajih in ustanovah ${ }^{8}$, a ga je prehitela smrt (ok. 1557). Tako pa je kot svoje glavno delo zapustil De admirandis Hungariae aquis hypomnemation ${ }^{9}$. Njegov opis ogrskih voda je bil očitno priljubljeno čtivo, zato so ga na veliko ponatiskovali. Prvi ponatis je v celoti, $\mathrm{z}$ vsemi sestavinami, izvzemši lesorez s podobo jezera, oskrbel kar Herberstein sam leta 1556 v Baslu (Herberstein 1556; Golia 1951: 211214), vendar pri tem ni postavil Wernherjevega imena na nič manj izpostavljeno mesto kakor v izvirniku, Wernherjevega avtorstva torej ni prikrival (prim. Shaw 1994: 350 in 355). Ta spis je bil pri takratnih geografih in etnografih očitno močno priljubljen, kmalu je izšel tudi $\mathrm{v}$ nemščini (Wernher 1558), nato so ga velikokrat ponatisnili, praviloma brez dodane podobe jezera. Pač pa je bila prejkone po prvotnem lesorezu narejena kopija v bakrorezu, objavljena v Kölnu 1595 (Broniowski 1595).

Ker $\mathrm{v}$ slovenščini, kolikor vem, nimamo opisa Cerkniškega jezera (mestoma napačen angleški prevod je objavil Shaw 1992: 269-270) in tistih partij Wernherjevega pisemskega traktata, ki poleg Herbersteinovega zgornjega pisma osvetljujejo razmerje med obema možema, naj sledi najprej prevod zadevnih delov besedila:

\footnotetext{
${ }^{8}$ "a me dicetur prolixius ea in commentatione, qua res Hungariae, et populorum in ea origines, appellationes, leges, mores, instituta conor explicare. (Wernher 1551: fol.2r)

${ }^{9}$ Sicer zelo zanesljivi izdajatelj pisem Erazma Rotterdamskega pravi - žal brez vsakršnega dokazila - , da je delo napisal leta 1528, a ga natisnil 1551 (sic, Allen 1928: VII, 270)
} 
reprinted a number of times, usually without the added picture of the lake. However, the original woodcut has been copied as a copper engraving, published in Cologne in 1595 (Broniowski 1595).

To the best of my knowledge, there is no integral English translation either of the description of Lake Cerknica (an incomplete and partly incorrect version was published by Shaw 1992: 269-270) or of those passages from Wernher's epistle which, in addition to Herberstein's letter cited above, illustrate the relationship between the two men. Therefore I begin by quoting the relevant passages in a new translation:

On the Marvellous Waters of Hungary to Sigismund, Baron of Herberstein, Neiperg and Guttenhag [Hrastnik] etc., Georg Wernher.

By your command, truly magnificent Baron Sigismund, I had set down some facts concerning the marvellous nature of the waters contained in the territory of our Zepusium [Spiš], so that you might confirm, with me as an eyewitness, the rumours which some people had heard from others and considered mere fables. My account was believed; indeed, it even inflamed some persons with a desire to learn more things of this sort. Not at all unwilling, I thus took up, as was my duty, the new task which you had considered fit to entrust me - viz., to encompass in writing still other marvellous, well-nigh miraculous waters which may be seen in our Pannonia. [. . . $]^{10}$

\section{The lake at Zirknitz [Cerknica].}

I remember your telling me once of a Carniolan lake, named Zirknitz [Cerknica] after the nearby village, a story no less amazing than my own account of the Hungarian waters: every year, the lake is flooded in late autumn with waters suddenly bursting from the hidden depths, carrying along a great multitude of fish, and at the approach of summer it dries up, with the waters seeking the depths again; these events alternate perpetually, so that you may reap and sow, as well as hunt at will, where you have been fishing but a little while ago, and when the year turns, you may fish again.

But what is there to prevent me from describing, on the basis of your conversation, the appearance of the place, as you have received it sketched by others? You said that it

${ }^{10}$ There follows the "Hungarian part" of the aquatic curiosities.
O čudovitih vodah Ogrske Sigismundu baronu

Herbersteinu, Neipergu in Hrastniškemu itn., Georg Wernher.

Na Tvoj ukaz, zares veličastni baron Sigismund, sem pred časom zabeležil nekaj podatkov o čudovitih lastnostih vodá na ozemlju našega Spiša, da bi Ti potrdil, kar sem videl na svoje oči, nekaterim, ki so od drugih o tem samo kaj slišali, pa velja za pravljico. A ker so ljudje ne le verjeli moji pripovedi, ampak se je nekaterim zbudila tudi želja, da bi o takšnih stvareh izvedeli še več, sem se, kot je bila moja dolžnost, zelo rad lotil naloge, ki se Ti jo je zdelo potrebno naložiti mi - naj zajamem v svoj opis še druge čudovite, še več, skorajda čudežne vode, ki jih je videti v naši Panoniji. [.. . $]^{10}$

\section{Jezero pri Cerknici.}

Spominjam se, da si mi o nekem jezeru na Kranjskem, ki se imenuje po bližnji vasi Cerknici, nekoč pripovedoval nič manj začudenja vredne stvari, kakor sem jih jaz navajal o ogrskih vodah, da se namreč to jezero vsako leto pod konec jeseni nenadoma napolni $z$ vodami, ki prihajajo iz globin in s sabo prinesejo množico rib: ko pa se bliža poletje, si vode spet poiščejo pot $v$ globine in jezero se posuši, in sicer $v$ nenehnem menjavanju, tako da lahko na kraju, kjer si prej ribaril, seješ in žanješ, obenem pa po mili volji loviš in, ko se leto spet obrne, ribariš.

Toda kaj brani, da ne bi po tvojem pripovedovanju opisal podobe kraja, ki si jo prejel narisano od drugih? Povedal si, da ga kroginkrog obdajajo gore, s katerih pritekajo vsak po svoji strugi neki neugledni potoki, in sicer trije od vzhoda, štirje od juga; dalj ko tečejo, manj imajo vode, saj jo popije zemlja, dokler jih naposled ne posrkajo vase takšni skalnati ponori, da bi se lahko zdelo, da so jih izklesale človeške roke. Ko tukaj vodé tako narastejo, da jih ponori ne morejo več požirati, jih izmečejo nazaj in ne samo ne pripustijo vase nič vode, ampak tudi vse, kar je bilo v njih, izbruhajo s tako naglico, da bi pred silovitostjo in navalom vzvratnega toka stežka ubežal še tako urno bežeč jezdec. Do kamor že se odpira kraj (sega pa kako poldrugo miljo ${ }^{11} v$ dalj in manj $v$ šir), se tako razlijejo vodé in ustvarijo jezero, ki je večinoma globoko osemnajst komolcev, kjer je najmanj globoko, pa doseže naravno velikost človeka.

\footnotetext{
${ }^{10}$ Sledi »ogrski del« vodnih znamenitosti.

${ }^{11}$ Tako imenovana nemška milja = ok. $7.500 \mathrm{~m}$.
} 
is enclosed by hills, from which there run humble streams, each in its own bed, three from the east and four from the south; the farther they flow, the feebler they gush forth, for the soil soaks up the water until it is finally absorbed by rocky sinks, shaped as if they had been hewn out by human hands. When the waters have overflowed this place until they can no longer be swallowed, they are regurgitated by the sinks; not only do these admit no more water, but they even spill forth whatever they have received, with such speed that even a fast-fleeing horseman would be hard pressed to escape the onslaught and onrush of the backflow. As far as the place stretches, then (for it stretches about one and a half miles ${ }^{11}$ in length, and less in breadth), the waters spread to form a lake, which is eighteen cubits deep in most places, and equals the stature of the human body at its shallowest.

Perhaps this will cause less amazement to one who knows that there are rivers in the region which sink underground and, having traversed great distances, flow back to the surface; moreover, that some of them, having once disappeared, never appear again. For he will reason that these waters flow into the lake by secret channels, especially if he learns that the same hills are hollowed out with huge caves, resounding with the roar of the rushing waters and containing pools of the same; there is the less doubt of the streams coming thence because live ducks are known to be carried by their currents into the open, and everyone knows that they cannot live in subterranean places lacking access to fresh air. But since it is considered certain that the increase of the waters is not brought from the hills by the streams or by other secret passages, but that it comes from the regurgitation - the spewing forth, so to speak - of the sinks, that it returns to its source and is resorbed, and that this happens at regular intervals: who will deny that these phenomena have nothing miraculous about them?

The phenomenon is the more striking because the waters draw back almost as speedily as they have advanced, not through the sinks alone but well-nigh everywhere through the soil, which soaks them up just as if they were pouring through a sieve. As soon as the country folk note this, they immediately block the larger passages as far as possible and flock together for fishing, which affords them not only pleasure but profit as well. It is easy to catch an enormous amount of fish, as they are left stranded by the water, and they are highly prized by the neighbours, where they are exported after being salted. But you would mostly find there - and this you might justly marvel at - pike (for

${ }^{11}$ The so-called German mile $=$ ca. 7,500 metres .
Temu se bo nemara manj čudil, kdor bo vedel, da so $v$ tej pokrajini reke, ki poniknejo $v$ zemljo in, potem ko tam premerijo dolge razdalje, spet pritečejo na površje, nekatere pa se, ko enkrat izginejo, celo sploh ne prikažejo več. Sklepal bo namreč, da se te vode po nekih skritih rovih zlivajo $v$ jezero, posebno še, če bo izvedel, da so prav tam na nekaj krajih $v$ gorah velikanske jame, iz katerih se sliš bobnenje deročih vodá, in v njih jezera stoječe vode; da prihajajo odtod tisti potoki, je mogoče dvomiti toliko manj, ker je znano, da voda prinese na dan žive race, o katerih pač vsakdo dobro ve, da ne morejo živeti v podzemlju, če tja ne pride zrak. Toda ker velja za dognano, da tisto naraščanje vodá ne more izhajati iz gorá po potokih ali drugih skritih dotokih, temveč da prihaja iz tistega povratnega izmetavanja, tako rekoč bruhanja ponorov, se spet vrača in vsrkne v svoje izhodišče, in sicer ob stalno se ponavljajočih časih - kdo bo rekel, da je pri tem kaj čudežnega?

Stvar je še bolj presenetljiva, ker se vode skoraj tako hitro, kakor so narasle, umaknejo ne samo skozi ponore, ampak jih domala povsod posrka zemlja ravno tako, kakor da bi se raztekle skozi rešeto. Ko to opazijo domačini, nemudoma kolikor le mogoče zamašijo večje odtoke in trumoma priletijo $k$ ribolovu, ki jim je ne le prijetno opravilo, ampak tudi veliko navrže. Zlahka namreč polovijo velikansko količino rib, saj se voda izpod njih odce$j a$, in pri sosedih, kamor jih nasoljene izvažajo, imajo dobro ceno. Našel pa boš tam, in temu se boš po pravici čudil, večinoma ščuke (teh je namreč v jezeru več kakor drugih rib), ki presežejo dva komolca; in to je dovolj velik dokaz, da so se morale zarediti ali vsaj zrasti v tistih žrelih in breznih, saj ni mogoče, da bi dosegle tolikšno velikost, medtem ko zunaj vode stojijo.

Ko se jezero posuši, je na vrsti žetev, koder so bila tla posejana; spet jih posejejo, preden jih poplavi voda. Tla sama so trdna, plodna in predvsem tako rodovitna s travo, da jo ponavadi požanjejo čez dvajset dni. Vendar pa njih plodnost ni enaka povsod, kajti precejšen del ne obrodi drugega kakor ločje.

Da bi postalo jezero bolj znano, bi rad dodal, kar si pristavil kot znamenito pripombo, da namreč leži približno miljo daleč od gradú, ki ga tako Italijani kakor Kranjci imenujejo Postojna; o njem si povedal, da so ga Benečani, dokler ne bi bila sklenjena pogodba, ki je bila zadnja med obema stranema, vzeli cesarju Maksimilijanu in ga, ko je bilo treba pogodbo in dogovor izpolniti, vrnili, na odličnem mestu gradú pa tako rekoč kot trofejo zapustili tadva verza, ki si ju tedaj prebral:

Ko je premagal Postojno, se vrača po vsem zmagovalec Léviad, prinašajoč lepe trofeje domov. 
these are more common in the lake than other fishes) exceeding two cubits in length; which is proof enough that they must be hatched, or at least bred, in those chasms, for they could not possibly attain this size while the waters were pooled outside.

When the lake dries up, it is time to harvest the sown plots, and there is a second sowing before the new flood. The soil itself is firm, fertile, and, above all, so productive of grass that the latter is usually cut after twenty days. But the fertility of the soil is not uniform, for a large area yields nothing but reeds.

To make the lake more recognisable, I would be delighted to add what you threw in as a memorable remark: that the lake is about a mile distant from a fortress called Postonia [Postojna] by Carniolans and Italians alike; you said that the Venetians had withheld it from Emperor Maximilian until the latest treaty between the two parties should have been struck, and when the time came to fulfil the agreement, they duly returned it, leaving on its illustrious spot, as if by way of a trophy, the following verses, which you then read:

Now that Postonia is vanquished and everything over, the victor,

Leviades [Maximilian I], returns, laden with trophies most fair.

But since what has been said about the rising of the waters at a set time reminds me of certain springs to which the same thing reputedly happens, I cannot refrain from discussing two, even though I have not considered it my task to treat foreign waters; let me thus repay you, in a manner of speaking, for what you have noted down from Arrian and Saxo Grammaticus about the same number of springs. $[\ldots]^{12}$

Here, glorious Baron, you have a booklet in place of a letter - a thinner one, to be sure, than you may have expected or the subject which you entrusted to me demanded. But as you know that I have very little time to spare, it will be consistent with your fairness to judge less my actual achievement than what I wanted to achieve. Certainly I have striven for one thing: to render a service to you.

The End.

${ }^{12}$ The spa at Pfäfers (Bad Ragaz) and a mountain spring at Aargau.
Ker pa me to, kar je bilo povedano o naraščanju vodá stalno ob istem času, spominja na neke vrelce, kjer se baje dogaja isto, si ne morem kaj, da ne bi, čeprav nisem imel namena obravnavati tujih izvirov, spregovoril o dveh primerih; tako naj se tako rekoč oddolžim za to, kar si zabeležil iz Arijana in Saksona Gramatika o enakem številu vrelcev. [. . .] $]^{12}$

Tu imaš, preslavni baron, $v$ obliki pisma knjižico, sicer resda bolj skopo, kakor si morda sam pričakoval ali je terjala snov, ki si mi jo dal v obravnavo. Ker pa dobro veš, da sploh nimam dovolj prostega časa, bo stvar Tvoje pravičnosti, da oceniš ne toliko, kaj sem dosegel, kakor kaj sem hotel doseči. Samó to, da bi Ti ustregel, pa sem zagotovo poskušal $z$ vso prizadevnostjo.

\section{Konec.}

Wernher sicer piše, da mu je Herberstein nekoč prej pripovedoval o Cekniškem jezeru in uporablja formulaciji memini te mihi... dicere, "spominjam se, da si mi govoril", in de sermone tuo describam, "opisal bom po tvojem pripovedovanju«, aiebas, "govoril si« ipd. Vsekakor drži, da npr. izraz sermo, katerega pomenski razpon sega od pogovora do bolj ali manj učenega razpravljanja ( $v$ cerkveni latinščini označuje pridigo), pomeni strogo vzeto samó ustno sporočanje. To je namreč posebej izpostavil Trevor R. Shaw in pravzaprav pripisal Herbersteinu zgolj vlogo prvega informatorja in pobudnika, torej vira, ki "persuaded Wernher to extend his studies to include the lakes of Hungary, which then embraced this part of Slovenia« (Shaw 1992: 96).

Shaw se je pri tem opiral na G. F. Pullenov žal napačni angleški prevod ključnega stavka, iz katerega pa je mogoče precej določno sklepati o načinu Herbersteinovega in Wernherjevega sodelovanja. V drugem odstavku opisa Cerkniškega jezera pravi Wernher: Sed quid obstat, quo minus loci faciem, ut eam ab aliis delineatam accepisti, de tuo sermone describam, kar lahko prevedemo v slovenščino: »Toda kaj [mi] brani, da ne bi po tvojem pripovedovanju opisal podobe kraja, ki si jo prejel narisano od drugih?" Pullenov povsem zgrešeni prevod pa pravi: »Yet the phenomenon perplexes me ... and I am not willing to accept all that is reported of it, so I will describe it from what you yourself have written." (Shaw 1992: 269; Shaw 1994: 354 opozarja samo na napačni »written« namesto »said« ali »told me«; presledek s pika-

\footnotetext{
${ }^{12}$ Toplice pri Pfäfersu (Bad Ragaz) in neki gorski studenec v Aargauu.
} 
To be sure, Wernher does state that Herberstein had talked to him about Lake Cerknica earlier: he uses such phrases as memini te mihi... dicere, "I remember your telling me," de sermone tuo describam, "I will describe on the basis of your conversation," aiebas, "you said," etc. And it is true that e.g. the term sermo, encompassing a range of meanings from "conversation" to a more or less learned "debate" (or "sermon" in church Latin), denotes, strictly speaking, only oral communication. This has been emphasised by Trevor R. Shaw, who sees Herberstein merely as the original informant and initiator, that is, as the source who "persuaded Wernher to extend his studies to include the lakes of Hungary, which then embraced this part of Slovenia" (Shaw 1992: 96).

Shaw's assessment is based on G. F. Pullen's unfortunately false English translation of the key sentence, which in fact suggests quite definitely the manner of Herberstein's and Wernher's collaboration. Wernher's second paragraph describing Lake Cerknica reads: Sed quid obstat, quo minus loci faciem, ut eam ab aliis delineatam accepisti, de tuo sermone describam, which may be rendered as: "But what is there to prevent [me] from describing, on the basis of your conversation, the appearance of the place, as you have received it sketched by others?" Pullen's completely mistaken translation, on the other hand, reads: "Yet the phenomenon perplexes me ... and I am not willing to accept all that is reported of it, so I will describe it from what you yourself have written." (Shaw 1992: 269; Shaw 1994: 354 only draws attention to the false "written" instead of "said" or "told me"; the ellipsis dots are Pullen's own insertion). But if the original is mined only for what it actually says, the following transpires: Herberstein must have given Wernher a detailed explanation of what was presented in a picture of the lake, while Wernher's argument - why not describe the lake simply on the basis of the picture and the Baron's explanation? - sounds almost apologetic. It seems as if Herberstein had wanted to help the foreigner, unfamiliar with the country, find his bearings around the lake, hence his "memorable remark" about the Postojna Castle and Emperor Maximilian. ${ }^{13}$ Wernher may well be envisioned taking notes of a relatively detailed account and description, to use them later in his Latin paraphrase of the Baron's report. The question whether Herberstein had actually provided Wernher with a written text of his own penmanship is today, of course, unanswerable.

For our purpose, then, Shaw's intensive search for the relevant printed or handwritten text by Herberstein is of secondary importance. His resulting conclusion is

${ }^{13}$ For more detail on the content of this paragraph and for an explanation of the two verses, see Simoniti 2010. mi je prevajalčev). Toda če razberemo iz izvirnika samo to, kar je v njem dejansko povedano, sledi, da je Herberstein ob sliki oz. upodobitvi jezera Wernherju nadrobno razložil, kaj je na njej prikazano, in Wernher se bralcu skorajda opravičuje, češ, zakaj pa pravzaprav ne bi smel jezera opisati kar po upodobitvi in baronovi razlagi. Vtis je, kot da bi mu, tujcu, ki ne pozna dežele, hotel Herberstein pomagati pri orientaciji v bližnji okolici jezera, zato je navrgel še »znamenito pripombo« o Postojnskem gradu in cesarju Maksimilijanu ${ }^{13}$. Predstavljati si je mogoče, da si je Wernher iz razmeroma nadrobnega pripovedovanja in opisovanja delal zapiske, po katerih je potlej v latinščini formuliral vsebino baronovega poročila. Ali je Herberstein napisal in Wernherju dal kot predlogo tudi kaj zapisanega, je danes seveda neugotovljivo.

Zato je za naš namen pravzaprav drugotnega pomena Shawjevo intenzivno iskanje ustreznega natisnjenega ali rokopisnega Herbersteinovega besedila; rezultat iskanja je sklep, ki se sklicuje na navedbo v dobrih 130 let mlajši Valvasorjevi Die Ehre - Slavi, kjer je v (najbrž Franciscijevem) "Verzeichniss aller derer Scribenten " $\mathrm{k}$ celotni Slavi (!) pod Herbersteinovim imenom navedeno kot njegovo delo »de Admirandis Rebus naturae (Valvasor 1689: I. zv., str. XLIV; Shaw 1994: 352). Podobnost tega navedka $\mathrm{z}$ naslovom Wernherjevega dela naj bi bila sestavljalca seznama zapeljala v zmoto, da je oboje pomešal in združil v nedokazljivi Herbersteinov spis.

Toda bolj povedno je neko drugo mesto v Slavi, in sicer v uvodnih partijah k opisu Cerkniškega jezera, kjer so med pisci, ki so od antičnega Strabona naprej omenjali to jezero, navedeni zaporedoma (Valvasor 1689: I. Bd., IV. Buch, 620):

[...] X. Auch deß Eduard Browens, welcher sowol in seinen Send=Briefen als in seiner Reis=Beschreibung Part VI. cap. 6 fol. 205 desselben [sc. Cerkniškega jezera] gedenckt.

XI. Das Send=Schreiben Freyherrn Sigmunds von Herberstein de admirandis rebus naturae. Wie man dann auch in theils andren Reis=Büchern und Schreiben der Peregrinanten hievon einen Bericht findet, sonderlich beym

XII. Georgio Wernero de admirandis Hungariae aquis, fol. $17[\ldots$, podčrtal P. S.]

Način Valvasorjevega citiranja (pri tiskih praviloma $\mathrm{z}$ navedbo lista ali strani, pri rokopisih brez) in izraz Send=Schreiben (pisanje, poslano s [poštnim] slom) na tem ključnem mestu omogočata sklep, da je šlo za rokopis, ki očitno ni bil nikdar natisnjen in ga moramo šteti za izgubljenega; če ga iščemo v natisnjeni obliki, pa najbrž res lovimo fantoma.

\footnotetext{
${ }^{13} \mathrm{O}$ vsebini tega odstavka in razlagi obeh verzov več Simoniti 2010.
} 
based on an entry in Valvasor's Die Ehre dess Hertzogthums Crain [The Glory of the Duchy of Carniola], a work written more than 130 years later, where the "Verzeichniss aller derer Scribenten" (presumably by Erasmus Francisci, Valvasor's collaborator and editor) for the entire Ehre (!) cites, under Herberstein's name, a treatise "de Admirandis Rebus naturae" (Valvasor 1689: Vol. I, p. XLIV; Shaw 1994: 352). The similarity between this entry and the title of Wernher's work supposedly misled the compiler of the list into confusing the two, merging them into a phantom treatise attributed to Herberstein.

More telling, however, is another passage in the Ehre, introducing the description of Lake Cerknica. Its list of authors who had referred to the lake, beginning with ancient Strabo, includes the following (Valvasor 1689: I. Bd., IV. Buch, 620):

[...] X. Auch deß Eduard Browens, welcher sowol in seinen Send=Briefen als in seiner Reis=Beschreibung Part VI. cap. 6 fol. 205 desselben [sc. Lake Cerknica] gedenckt.

XI. Das Send=Schreiben Freyherrn Sigmunds von Herberstein de admirandis rebus naturae. Wie man dann auch in theils andren Reis=Büchern und Schreiben der Peregrinanten hievon einen Bericht findet, sonderlich beym

XII. Georgio Wernero de admirandis Hungariae aquis, fol. 17 [. . ., underlined by P. S.]

Valvasor's citation style (the inclusion of sheet or page number for prints and its omission for manuscripts) and the term Send=Schreiben (writing sent by a [post] courier) in this key passage suggest reference to a manuscript which had, to all appearances, never been printed and must be considered lost; searching for a printed copy is probably a wild-goose chase indeed.

The question whether Valvasor had known Herberstein's cited manuscript or merely heard of it thus remains a matter of speculation, but it could hardly be claimed that he had simply invented it. Another parallel may be highlighted here: if the Baron's description of Lake Cerknica had been included in his hypothetical manuscript entitled De admirandis rebus naturae and composed in German, a language more congenial to the Baron than Latin, then Wernher's ignorance of it would have been odd - or he may have been satisfied with the Baron's oral report alone. In that case he would have acted as a "ghost writer", rephrasing the text in beautiful, elegant Latin - just as the text of Herberstein's Moscovia was very likely given its Latin form and polish by his

\footnotetext{
14 "Totus ille Commentariolus, si non fortuitus, certe ex auditionibus, partem maximam, collectus est," writes Matthias Belius (Velius) in the preface to J. G. Schwandtner, Scriptores rerum Hungaricarum I, Vindobonae 1746 (qtd. in Denis 1782: 474).
}

Slejkoprej lahko torej samo ugibamo, ali je Valvasor citirani Herbersteinov rokopis tudi poznal ali le slišal zanj, težko pa bi si upali trditi, da si ga je kar izmislil. Tu lahko opozorimo še na neko paralelo: če je bil kak baronov opis Cerkniškega jezera obsežen v njegovem domnevnem rokopisnem delu De admirandis rebus naturae $\mathrm{v}$ nemščini, ki je je bil baron bolj vešč kakor latinščine, bi bilo nenavadno, da Wernher ne bi bil vedel zanj - morda pa se je kar zadovoljil samo $\mathrm{z}$ baronovim ustnim poročilom. $\mathrm{V}$ tem primeru bi bil kot nekakšen "ghost writer « besedilo preformuliral v lepo, elegantno latinščino - podobno kot je besedilu Herbersteinovih Moskovskih zapisnikov zelo verjetno dajal latinsko podobo in stilizacijo njegov rojak in ščitenec, profesor poetike na Dunaju, Luka Dobrepoljski, imenovan tudi Gutenfelder ali Agathopedius (Simoniti 1979: 213-215; Simoniti 2008: 260-261; Harrauer 1982: 146-147).

Herberstein je imel zelo raznovrstne interese, med njimi ne nazadnje tudi naravoslovne, in je po Wernherjevih besedah vneto gojil preučevanje in raziskovanje "vsega, kar je pri spoznavanju naravnih pojavov in krajev bodisi nepojasnjeno bodisi čudenja vredno" (studium in his eruendis, quae in cognitione naturae rerum atque locorum vel obscura sunt, vel aliquam admirationem habent, Wernher 1551: fol. 13r), o čemer najbolje pričajo njegovi Rerum Moscoviticarum commentarii ali skrajšano Moskovija. Domačin Herberstein je jezero vsekakor dobro poznal in se zanj živo zanimal, medtem ko v 1551 natisnjenem Wernherhevem besedilu jezerskega opisa ni prav nobenega namiga ali indica o tem, da bi bil Wernher jezero res kdaj obiskal ali ga sam preučeval. Ta vtis potrjuje tudi struktura Wernherjevega spisa, ki je lepo razvidna iz seznama "poglavij« v opombah $\mathrm{k}$ latinskemu tekstu: Po uvodnem prikazu Panonije (fol.1r-2v) sledijo poročila o ogrskih toplicah, slatinah, vrelcih, rekah, mednje je vstavljen ekskurz o Turkih na Ogrskem (fol.3v5r); za sklep ogrskega dela so navedeni še poglavitni antični naravoslovni pisci, ki so pisali o nenavadnih vodah (fol.17r). Šele nato sledi nekakšen »dodatek iz druge roke«, in sicer daljše poročilo o Cerkniškem jezeru in kratka omemba dveh švicarskih vrelcev, o katerih da piše neki "novejši švicarski pisec kronik« (fol. 19r). A že dvesto let po izidu je bila o Wernerjevem delcu izrečena tudi zelo kritična sodba: njegov spis, da je »večji del zagotovo napaberkovan iz pripovedovanja«, tj. poslušanja drugih (ex auditionibus) ${ }^{14}$.

\footnotetext{
${ }^{14}$ "Totus ille Commentariolus, si non fortuitus, certe ex auditionibus, partem maximam, collectus est «, je zapisal Matthias Belius (Velius) v predgovoru k J. G. Schwandtner, Scriptores rerum Hungaricarum I, Vindobonae 1746 (cit. po Denis 1782: 474).
} 
countryman and protégé, a professor of poetics in $\mathrm{Vi}$ enna, Luke from Dobrepolje in Carniola, also known as Gutenfelder or Agathopedius (Simoniti 1979: 213-215; Simoniti 2008: 260-261; Harrauer 1982: 146-147).

Herberstein had a variety of interests, including natural science; according to Wernher, he zealously fostered inquiry and research into "everything which either remains unexplained or arouses some wonder in the study of natural phenomena and places" (studium in his eruendis, quae in cognitione naturae rerum atque locorum vel obscura sunt, vel aliquam admirationem habent, Wernher 1551: fol. 13r), which is best attested by his Rerum Moscoviticarum commentarii, or Moscovia for short. A native to those parts, Herberstein certainly knew the lake well and took a lively interest in it, whereas Wernher's description, printed in 1551, offers no hint or clue that Wernher had ever actually visited the lake or investigated it in person. This impression is corroborated by the structure of Wernher's treatise, evident from the list of "chapters" in the margins of the Latin text: An introductory survey of Pannonia (fol.1r-2v) is followed by reports on Hungarian spas, mineral waters, springs, rivers, including a digression on the Turks in Hungary (fol.3v-5r); the Hungarian part concludes with a list of the major natural science writers from antiquity who had discussed extraordinary waters (fol.17r). Only then does a "second-hand appendix" follow: a fairly long report on Lake Cerknica and a brief mention of two Swiss springs, which are said to be discussed by a "recent author of Swiss chronicles" (fol. 19r). But no later than two hundred years after its publication, Wernher's treatise was subjected to the severe criticism that it must have been, "for the most part, patched together from interviews" (ex auditionibus). ${ }^{14}$

The decisive proof of, and key to, Herberstein's coauthorship of the lake description is that it was he who had conveyed to Wernher the "appearance of the place", which had been "sketched" for him "by others" (loci faciem ... ab aliis delineatam accepisti) and appended as a woodcut on a double folded sheet to the 1551 print (as well as to the 1558 German edition, and copied in 1595 as a copper engraving). The Baron had engaged a number of artists to furnish maps and many other illustrations, both for his Moscovia and for other publications, such as Gratae posteritati (Golia 1951; Harrauer 1982: 150 and 152-153). As Janez Höfler has kindly pointed out, it is thus not only possible but highly likely that the motif for the woodcut of Lake Cerknica had been drawn by the famous Nürnberg painter, graphic artist and cartographer, Augustin Hirschvogel (1503-1553), who had worked in Ljubljana since 1536, drawn, by King Ferdinand I's commission, maps of Carinthia and Carniola (among others), and moved in 1544 to Vienna, where he had completed by 1546 the illustrations and maps

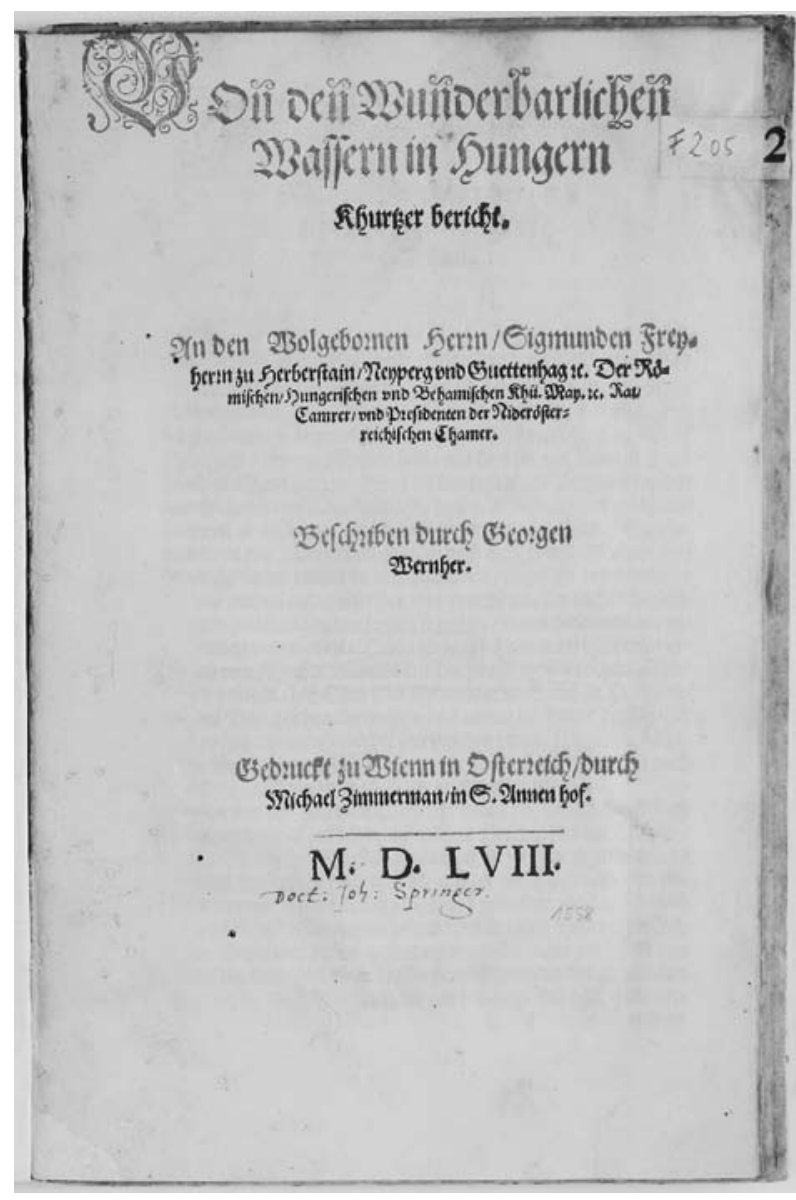

Fig. 4: Title page of the German publication 1558 - UB Erlangen, sign. 2 Trew F 205.

Sl. 4: Naslovna stran nemške izdaje 1558 - UB Erlangen, sign. 2 Trew F 205.

Poglavitni dokaz za Herbersteinovo soavtorstvo za opis jezera in ključ do njega pa je dejstvo, da je ravno on sam posredoval Wernherju "podobo kraja", ki jo je dobil ali prejel "narisano od drugih" (loci faciem ... ab aliis delineatam accepisti) in ki je bila kot lesorez na dvojnem preganjenem listu priložena $\mathrm{k}$ natisu iz leta 1551 (in v nemški izdaji 1558 ter kot bakrorez prekopirana 1595). Baron je sploh angažiral kar precej izdelovalcev geografskih kart in številnih drugih ilustracij tako za svojo Moskovijo kakor tudi za druge publikacije, npr. Gratae posteritati (Golia 1951; Harrauer 1982: 150 in 152-153). Zato je po prijaznem sporočilu Janeza Höflerja ne le povsem mogoče, ampak celo zelo verjetno, da je predlogo za lesorez Cerkniškega jezera narisal znameniti nürnberški slikar, grafik in kartograf Augustin Hirschvogel (1503-1553), ki je od leta 1536 deloval v Ljubljani, naredil po nalogu kralja Ferdinanda I. med drugim karto Koroške in Kranjske in se 1544 naselil 
for Herberstein's Rerum Moscoviticarum commentari (Pilz 1972). Based on Hirschvogel's drawing style, which is displayed by his etchings as well, and on the similarities to the illustrations in the Commentarii, Höfler is "increasingly convinced that the drawing must be his work"; "the historical circumstances must be considered as well, for we know of no other contemporary artist in Slovenia capable of drawing such a map." According to Höfler, this was a masterpiece by an accomplished artist, even though many a finesse would have been lost in transferring the drawing to the woodcut.

All these reasons favour the hypothesis that Herberstein had described Lake Cerknica, with references to its picture, in his conversations with Wernher. Being native to those parts, he knew it very well; he possibly prepared a report in German and probably commissioned the drawing and woodcut from Augustin Hirschvogel or his workshop. His report was adapted in Latin by Georg Wernher, who did not know the lake from autopsy, and attached as a "non-Hungarian" appendix to his descriptions of Hungarian waters.

Translated by Nada Marija Grošelj na Dunaju, kjer je do 1546 za Herbersteinove Rerum Moscoviticarum commentarii izdelal ilustracije in karte (Pilz 1972). Höfler je glede na Hirschvoglov risarski način, ki ga kažejo tudi njegove jedkanice, in glede na podobnosti z ilustracijami v Moskovskih zapiskih »vse bolj prepričan, da je predloga v resnici njegovo delo«; "upoštevati je treba tudi zgodovinske okoliščine, saj ne poznamo nikogar drugega, ki je tedaj bival v naših krajih in bi bil mogel narediti tako karto«. Vsekakor gre po Höflerju za izvrstno delo odličnega mojstra, čeprav je računati tudi s tem, da se je ob prenosu risbe $\mathrm{v}$ lesorez izgubila marsikatera finesa.

Vsi ti razlogi govorijo $\mathrm{v}$ prid domneve, da je Herberstein opisal Cerkniško jezero ob upodobitvi v pogovorih z Wernherjem; sam ga je kot domačin dobro poznal, morda pripravil kakšno $\mathrm{v}$ nemščini napisano poročilo in prejkone dal izdelati risarsko predlogo in lesorez pri Augustinu Hirschvoglu oz. v njegovi delavnici. Njegovo poročanje je nato $\mathrm{v}$ latinščini priredil Georg Wernher, ki jezera ni poznal iz avtopsije, ter ga kot »neogrski« dodatek priključil svojim opisom ogrskih vodá.

\section{APPENDIX $^{15} /$ PRILOGA $^{15}$}

De admirandis Hungariae aquis hypomnemation ad generosum et vere magnificum D. Sigismundum in Herberstain, Neiperg \& Guttenhag Baronem, inclyti Roman. Hung. \& Boëm. \&c. regis, D. Ferdinandi consiliarium, \& fisci in Austria praefectum. Georgio Wernhero autore. - Viennae Austriae excudebat Egidius

Aquila, anno Domini M. D. LI. mense Septembri. $-[5]+20+[1]$ fol.; $14,5 \times 18,5 \mathrm{~cm}, 4^{\circ}$

fol. A4r-B1r

Sigismundus liber baro in Herberstain, Neyperg et Guttenhag etc.

Georgio Wernhero regio consiliario et apud Saros praefecto S. D.

Etsi iam olim, et a multis quidem multa de admirandis in Zepusio aquis audieram, tamen iisdem de rebus, quae plaerisque incredibiles videbantur, a te imprimis certior fieri, et tuum iudicium audire desiderabam.

${ }^{15}$ The abbreviations are, as a rule, resolved, the usage of capitals and the letters $i$ and $j, u$ and $v$ is normalised.

${ }^{15}$ Okrajšave praviloma razvezane, normalizirana je raba velikih začetnic ter črk $i, j$, $u$ in $v$.
Quia vero non dubitasti, quae comperta de his haberes, ad me scribere, facile effecisti, ut non modo, quid ipse posthac de his sentire debeam, certo scirem, sed etiam multi alii excellentes viri testimonio tuo, cui plurima apud omnes est auctoritas, confirmati addubitare desinerent. Sed cum etiam in reliquis Hungariae partibus multae non minus admirabiles aquae esse dicantur, rem valde gratam mihi, et multis aliis harum rerum cupidis, tuique studiosis facturus es, si eas quoque describendas susceperis. Scio quidem, et vidi ipsemet apud serenissimum quondam Ludovicum Hungariae regem, divi imperatoris Maximiliani legatione fungens ad Budam sedem regiam, thermas esse, quorum [sic] calorem immissa manu ferre nequeas, quod ei utique, qui ante non vidit, mirabile videtur. Sed quod in his etiam vivi pisces sunt, id non pauci pro re incredibili habent. Talia quoque videntur esse, quae dicuntur de aliis thermis in ripa fluvii Vagi, non longe ab oppido Galgocz, quod Germani et Slavi vulgo Freistat vocant, quas locum, prout crescit aut decrescit fluvius, in aequali semper distantia mutare aiunt. Legi nuper apud Arrianum libro tertio descriptum fontem, qui sub lucem tepentibus aquis manat, in meridie frigidus, vesperi calet, ac sub exortum diei rursum tepidus oritur, atque ita per singulos dies ac noctes aestus ac frigoris vices variat. Saxo Grammaticus in Islandia 
fontem esse testatur, qui fumigantis aquae vitio nativam rei cuiuslibet originem demolitur. Nam quicquid humido eius vapore afflatur, in lapideae naturae duriciem, forma tantum superstite, subita conversione transmutari. Haec et his similia, qui deinceps legent, minus mirabuntur, ubi animadvertent summum opificem in his etiam nostris et aliis vicinis regionibus non pauca mirabilium operum suorum monimenta posuisse, quae tamen indigenae pro miraculis non habent, ac quandoque etiam, si interrogantur, ignorant, quemadmodum in Moscovia saepenumero sum expertus. Nam cum nonnulla eiusmodi, quae mihi narrarant alii, quaererem ab incolis, adeo nihil habebant, quod responderent, ut mirari se dicerent, unde ea homo peregrinus accepissem. Non dubium est autem, nisi plaeraque diversis in locis observassent, et literis mandassent homines externi, quin ea indigenarum negligentia nunc luce suique memoria, et admiratione carerent. Non potest igitur mihi, Wernhere ornatissime, non valde probari studium tuum, quod hoc genus Hungariae tuae rebus eruendis, et illustrandis impendis, nec facere possum, quin te ad id continuandum cohorter. Nam eo non tantum mihi fueris gratificatus, sed etiam tibi apud omnes magnae laudi est futurum. Bene vale.

fol. $1 r$

De admirandis Hungariae aquis Sigismundo in Herberstein, Neiperg et Guttenhag baroni etc. Georgius Wernherus.

Annotaram iussu tuo nonnulla, Sigismunde baro vere magnifice, de mirabilibus aquarum naturis, quae finibus Zepusii nostri continentur, ut me ceu oculato teste confirmares ea, quae quidam audita ab aliis pro fabulosis habuerunt. Quia vero non modo fides habita est narrationi meae, sed etiam quibusdam incensa cupiditas plura hoc genus cognoscendi, minime invitus, ut debui, suscepi, quod mihi denuo mandandum duxisti, ut alia quoque aquarum miracula, quae in Pannonia nostra visuntur, non minus pene prodigiosa scripto complecterer. [... $]^{16}$ fol. $17 v-19 r$

\section{Lacus ad Zirknitz}

Memini te mihi aliquando de quodam in Carnis lacu, cui a pago vicino Zirknitz nomen est, non minus pene miranda dicere, quam a me de Hungariae aquis sunt memorata, ut is videlicet quotannis fere sub autumni finem, aquis de repente ex abdito venientibus, magnamque piscium copiam secum trahentibus, inundetur: appetente vero aestate aquis rursus abdita petentibus exarescat, haec quasi perpetua vicissitudine, ut quo in loco paulo ante piscatus fueris, in eo messem et sementem facere, simulque si libeat venari, ac rursus vertente anno piscari possis.

Sed quid obstat, quo minus loci faciem, ut eam ab aliis delineatam accepisti, de tuo sermone describam. Claudi aiebas eum circumquaque montibus, e quibus rivi quidam ignobiles suo quisque alveolo procurrant, $\mathrm{ab}$ orientali quidem plaga tres, ab australi quatuor : singulos quo longius fluant, hoc minus scatere aquis, terra nimirum ipsas combibente, donec postremo absorbeantur scrobibus saxeis, ita natis, ut humano opere excisae videri possint. Hic aquis ita redundantibus, ut recipi non possint, fieri, ut regurgitent scrobes, neque solum nihil aquae admittant, sed etiam quicquid receperint, effundant tanta rapiditate, ut refluxus impetum ac cursum equiti quamvis expedito et fugienti, aegre effugere liceat. Itaque quacunque pateat locus (patere autem eum ad sesquimilliarium minus laxa latitudine) diffundi aquas, et lacum efficere, qui plaerisque in locis decem et octo cubitos altus sit, et ubi minimum profundus est, aequet iustam humani corporis mensuram.

Haec forte minus mirabitur, cui constabit esse eadem in regione amnes, qui terras subeant, et ubi per longa spacia mearint, rursus effluant, quosdam etiam ubi semel sese abdiderint, amplius non comparere. Nam hinc occultis quibusdam canalibus illas in lacum manare aquas ratiocinabitur, praesertim si cognorit ibidem aliquot in locis esse cava montium amplissima, in quibus aquarum ruentium fremitus exaudiatur, et earum quasi stagna sint, unde illos venire rivos hoc minus dubium videri potest, quod constat iisdem anates vivas evehi,

\footnotetext{
${ }^{16}$ [Sequuntur capita:] Pannonia - Montes Sarmatici. Carpatus - Tibiscus. Transylvania - Oppida montana - Comitatus Hungariae - Comites - Calidae ad Budam - Calidae frigidis contiguae - Derbisae Turcarum - Turcarum lotiones - Pietas apud Turcas condere balnea publica - Pisces vivi in calidis - Calidae ad Pesth - Loca a calidis nobilitata - Budae nomen - Vvesprimium - Calidae ad Strigonium - Calidae ad Pesthien. in ripa Vagi - Calidae prope Trincinium - Calidae ad Baimocz - Calidae ad Stubnam - Calidae prope Semniciam - Calidae Roselinae - Tepidae ad divi Ioannis - Rupes Sarmatiae - Zepusium - Aqua ferrum rodens - Cuprum ex ferro - Vitriolum duplex - Aquae lapidescentes - Rauschenpach - Aqua aestate glaciata - Fontes letales - Fontes acidi - Aqua viridis - Specus letali halitu - Acidulae - Acidula saporem mutans - Acidula et alia lapidescens - Stillaticia lapidescens - Fontes salsi - Sal saxeus - Pisces vivi in salsa aqua - Excisa de medio sale ligna - Flos salis - Sal Polonicus - Calidae ad Vvaradinum - Frigidae salutares - Georgius Agricola - Moscovia Sigismundi Herberstainii - Hungarorum origo et nomen - Insignes Hungariae quatuor amnes - Amnes auriferi - Massae auri effossae - Tibisci ortus - Copia piscium in Tibisco - Vilitas piscium - Miracula aquarum qui autores potissimum scripserint.
} 
quas nemo nescit in locis subterraneis, in quae aurae aditus non sit, degere non posse. Sed quia pro comperto habetur illam aquarum accessionem non duci e montibus per rivos, aut alios occultos meatus, sed venire $a b$ illa scrobium regurgitatione, et quasi vomitu, rursusque eodem redire, et resorberi, idque statis temporibus fieri, quis haec miraculo carere negabit?

Auget vero hoc quoque rei novitatem, quod fere non minus celeriter recedunt aquae, quam accesserunt, non per scrobes illas tantum, sed universa pene terra non aliter eas recipiente, quam si per cribrum diffunderentur. Quod cum fieri sentiunt accolae, continuo grandioribus eius meatibus, quoad fieri potest, obstructis agminatim advolant ad piscationem, quae ipsis non modo iucunda, sed etiam perfructuosa est. Nam et piscium vis ingens facile capitur, aqua nimirum eos destituente, et apud vicinos precium habent, ad quos conditi sale exportantur. Invenias autem ibi plaerumque, quod iure mireris, lucios (nam his magis quam aliis piscibus abundat hic lacus) qui duos cubitos excedant, quae res satis est magno argumento, eos intra illas voragines nasci, aut saltem augeri oportere, cum fieri non possit, ut dum foris stagnant aquae, ad tantam magnitudinem perveniant.

Porro siccato lacu fit messis, qua parte solum consitum, et idem rursus conseritur antequam inundet. Solum ipsum firmum, laetum, et in primis ita ferax graminis, ut post vigesimum diem secari soleat. Non est tamen eadem ubique foecunditas. Nam magna eius pars praeter iuncum nihil gignit.
Quo vero magis cognobilis fiat lacus, libet addere, quod tu ceu insignem notam adiecisti, nempe distare eum ad unius milliarii spacium ab arce Carnis pariter et Italis dicta Postonia, quam Venetos aiebas Maximiliano imperatori, dum percuteretur foedus, quod inter eos postremum fuit, ademisse, et dum pacta conventa praestari oporteret, reddidisse, in illustri eius loco tanquam pro trophaeo relictis his versibus, quos ibi tum legeris,

Postonia victa rediens post omnia victor

Leviades affert pulchra trophaea domum.

Quia vero id, quod dictum est de aquarum ad statum tempus accessione, me quorundam fontium, quibus idem accidere dicitur, admonet, etsi mihi externa minime persequenda duxi, facere tamen non possum, quin de duobus dicam, ut tibi illud quasi pensem, quod ex Arriano et Saxone Grammatico de totidem fontibus annotasti. $[\ldots]^{17}$

\section{fol. $20 r$}

Habes baro clarissime, pro epistola libellum magis ieiunum quidem illum, quam vel ipse forte exspectabas, vel materia, quam mihi tractandam dederas, exigebat. Sed cum non ignores me minime abundare ocio, tuae erit aequitatis non tam, quid assecutus sim, quam quid assequi voluerim, aestimare. Hoc unum quidem certe, ut tibi gratum facerem, sedulo sum conatus.

Finis.

\section{ACKNOWLEDGEMENT}

The author is grateful to Janez Höfler, Andrej Kranjc and Marija Wakounig for their invaluable assistance, and to
Nada Marija Grošelj for her excellent English translation from Slovenian and Latin.

${ }^{17}$ [Sequuntur] Calidae ad Pfeuers - Fons in Helvetiis. 


\section{PREFERENCES}

Allen, P. S., 1928: Opus epistolarum Des. Erasmi Roterodami, tom. VII 1527-1528.- Clarendon, pp. 560, Oxford.

Bauch, G., 1901: Deutsche Scholaren in Krakau in der Zeit der Renaissance 1460 bis 1520.- Friedrich, pp. 80, Breslau (Sonderdruck aus dem 78. Jahresbericht der Schlesischen Gesellschaft für vaterländische Kultur).

Broniowski, M., 1595: Martini Broniovii ... Tartariae descriptio. Item Transsylvaniae ac Moldaviae... descriptio Georgii a Reichersdorff. Praeterea Georgii Werneri De admirandis Hungariae aquis hypomnemation.- Mylius, Coloniae Agrippinae.

Denis, M., 1782: Wiens Buchdruckergeschicht bis MDLX.Wappler, Wien.

Golia, L. M., 1951: Bibliografija.- In: Herberstein, S., Moskovski zapiski. Državna založba Slovenije, pp. 208-226, Ljubljana (reprint Slovenska matica, Ljubljana 2004).

Harrauer, C., 1982: Die zeitgenössischen lateinischen Drucke der Moscovia Herbersteins und ihre Entstehungsgeschichte (Ein Beitrag zur Editionstechnik im 16. Jh.).- Humanistica Lovaniensia 31, 141-163.

Herberstein, S., 1556: Rerum Moscoviticarum commentarii...- I. Oporinus, Basileae.

Herberstein, S., 1560: Gratae posteritati... actiones suas brevi commentariolo reliquit.- $\mathrm{R}$. Hofhalter, Viennae Austriae.

Jaumann, H., 2006: Handbuch Gelehrtenkultur der Frühen Neuzeit. Band 1: Bio-bibliographisches Repertorium.- De Gruyter, pp. 722, Berlin, New York.

Pilz, K., 1972: Hirschvogel (Hirsvogel), Augustin.- In: Neue deutsche Biographie. Band 9. Dunker und Humblot, pp. 231-232, Berlin.

Shaw, T. R., 1992: History of Cave Science. The Exploration and Study of Limestone Caves, to 1900. Second Edition.- Sydney Speleological Society, pp. XIV, 338, Sydney.
Shaw, T. R., 1994: Baron Herberstein on the Cerknica Karst Lake - A Phantom Book of the 16th Century?- Acta carsologica, 23, 349-357.

Shaw, T., 2009: Cerkniško jezero v Frischlinovi pesmi iz okoli leta 1583 in Steinbergovi knjigi iz leta 1761.Kronika, 57, 1-18.

Simoniti, P., 1979: Humanizem na Slovenskem in slovenski humanisti do srede XVI. Stoletja.- Slovenska matica, pp. 300, Ljubljana.

Simoniti, P., 2008: Humanismus bei den Slovenen. Slovenische Humanisten bis zur Mitte des 16. Jahrhunderts. Herausgegeben und bearbeitet von Marija Wakounig, übersetzt von Jože Wakounig.- Verlag der Österreichischen Akademie der Wissenschaften, pp. 344, Wien (Zentraleuropa-Studien 11).

Simoniti, P., 2010: Postojnski grad v letu 1508 in Maksimilijan I. z vzdevkom »Leviades«.- Zgodovinski časopis, 64, forthcoming.

Valvasor, J. W., 1689: Die Ehre dess Hertzogthums Crain.Endter, Laybach-Nürnberg (2te unveränderte Auflage Krajec, Rudolfswerth 1877).

Wernher, G., 1551: De admirandis Hungariae aquis hypomnemation ad generosum et vere magnificum $D$. Sigismundum in Herberstain, Neiperg \& Guttenhag Baronem, inclyti Roman. Hung. \& Boëm. \&c. regis, D. Ferdinandi consiliarium, \& fisci in Austria praefectum.- Aquila, Viennae Austriae. - Also available online at www.digitale-sammlungen.de (without the map!).

Wernher, G., 1558: Von den wunderbarlichen Wassern in Hungern Khurtzer bericht. An den Sigmunden freyherrn zu Herberstain... Geschriben durch Georgen Wernher.- Zimmermann, Wien. 